\title{
PENGARUH IKATAN BISNIS DAN POLITIS TERHADAP KINERJA PERUSAHAAN: EFEK MODERASI KETERGANTUNGAN PADA PARTNER
}

\author{
Badri Munir Sukoco \\ Fakultas Ekonomi dan Bisnis, Universitas Airlangga \\ e-mail: badri@feb.unair.ac.id \\ Ibrahim \\ Fakultas Ekonomi dan Bisnis, Universitas Airlangga \\ e-mail: jokeibra@gmail.com
}

\begin{abstract}
Social capital of firms, either business or political ties, contributes positively on their performance. However, prior studies rarely examine whether business or political ties that contribute to firms' performance. Based on social capital theory, we argue that business ties have greater contribution on Indonesian firms' performance than political ones. Further, we predict that interdependency toward partner, either in business or politics, could strengthen the relationship between social capital and performance. A survey was conducted among 154 business managers or owners enlisted in KADIN Surabaya. Interestingly, political ties have greater influence on firms' performance than business ties. High interdependency toward business or political partners could strengthen the positive influence of social capital on performance. Managerial and academic implications are further discussed.
\end{abstract}

Keywords: business ties, political ties, interdependency, social capital theory, and performance

\begin{abstract}
Abstrak
Sumberdaya sosial (social capital) yang dimiliki perusahaan, baik berupa ikatan bisnis maupun politis, berkontribusi secara positif terhadap kinerja perusahaan. Namun, studi sebelumnya jarang menguji secara empiris apakah ikatan bisnis atau politis-kah yang berkontribusi terhadap kinerja perusahaan. Berdasarkan teori modal sosial, kami berargumentasi bahwa ikatan bisnislah yang berpengaruh lebih dominan terhadap kinerja perusahaan di Indonesia dibandingkan ikatan politis. Lebih lanjut, kami menggambarkan bahwa ketergantungan terhadap partner, baik partner bisnis maupun politis, akan memperkuat hubungan antara ikatan bisnis maupun politis terhadap kinerja perusahaan. Dengan melakukan survey terhadap 154 manajer atau pemilik perusahaan yang terdaftar pada KADIN Surabaya, hasil penelitian menunjukkan bahwa ikatan politis yang dimiliki pengusaha berpengaruh lebih dominan terhadap kinerja perusahaan. Ketergantungan yang tinggi terhadap partner (bisnis maupun politis) akan memperkuat hubungan antara ikatan yang ada terhadap kinerja perusahaan. Implikasi akademis dan manajerial akan dibahas lebih lanjut dalam tulisan ini.
\end{abstract}

Kata kunci: ikatan bisnis, ikatan politis, ketergantungan, teori modal sosial, dan kinerja perusahaan

\section{PENDAHULUAN}

Dibandingkan negara lain, Indonesia relatif beruntung kurang terimbas oleh krisis ekonomi yang menjangkiti USA dan Eropa. Bahkan pertumbuhan ekonomi Indonesia tetap positif dan diproyeksikan stabil diatas $6 \%$ pada tahun ini. Dengan kondisi perekonomian yang menjanjikan, Indonesia menarik banyak pelaku bisnis untuk memperebutkan pasar domestik yang cukup besar. Menurut Zhou and Poppo (2010), sebagai negara dengan pertumbungan 
ekonomi tinggi dan stabil, Indonesia akan mengalami banyak perubahan yang terkait dengan bidang ekonomi, sosial, dan peraturan. Dalam lingkungan yang sangat kompetitif, memiliki modal sosial (social capital) sangat penting untuk mengamankan sumberdayasumberdaya strategis dalam memenangkan persaingan (Ambler and Witzel, 2004; Peng, 2003). Modal sosial penting dalam menjembatani pertukaran secara informal dengan pelaku usaha lainnya (Granovetter, 1985) bilamana mekanisme formal tidak berjalan dengan baik (Xin and Pearce, 1996), terutama ketika lingkungan memiliki tingkat ketidakpastian yang tinggi (Heide and Wathne, 2006; Uzzi, 1997).

Hasil penelitian sebelumnya menyatakan bahwa modal social berkontribusi positif terhadap kinerja pemasaran (Gu et al., 2008; Li and Zhang, 2007) dan kinerja keuangan perusahaan (Khwaja and Mian, 2005; Li et al., 2008) di negara-negara berkembang. Namun Sheng, et al. (2011) berargumentasi bahwa hasil penelitian tersebut masih belum menjawab modal sosial yang bagaimanakah yang perlu dikembangkan perusahaan. Lebih lanjut, mereka mengkategorikan modal sosial menjadi dua, yakni ikatan bisnis dan ikatan politis. Ikatan pertama adalah hubungan yang dimiliki perusahaan dengan mitra bisnisnya, sedangkan ikatan kedua adalah hubungan yang dimiliki perusahaan dengan pejabat pemerintah. Penelitian yang mereka lakukan di Guangdong dan Shanghai menunjukkan bahwa ikatan bisnis lebih superior dalam berkontribusi terhadap kinerja perusahaan dibandingkan ikatan politis.

Meskipun reformasi telah berlangsung sejak 1998, namun kedekatan dengan penguasa (baik di tingkat kabupaten/kota, provinsi, bahkan nasional) hingga saat ini masih dijadikan andalan dalam meningkatkan kinerja perusahaan. Hal ini dikarenakan peranan pemerintah di Indonesia, sebagaimana negara berkembang lainnya, sangat besar dalam perekonomian. Pengeluaran pemerintah berupa proyek-proyek infrastruktur, perizinan usaha, perlakuan khusus terkait pajak, dan lainnya masih dipegang oleh pemerintah melalui pejabat yang ditunjuk. Hal ini seperti yang diungkapkan oleh Fisman (2001) dan Dieleman and Sachs (2008) bahwa kedekatan ikatan politis dengan rezim Soeharto merupakan faktor terpenting kesuksesan sebuah perusahaan karena akses yang lebih luas terhadap sumberdaya-sumberdaya yang dikuasai negara. Yang menjadi pertanyaan adalah, apakah kondisi yang demikian menjadikan ikatan bisnis yang dimiliki oleh pengusaha Indonesia tetap menjadi faktor yang lebih berpengaruh terhadap kinerja perusahaan dibandingkan ikatan politis?

Hillman and Hitt (1999) menyatakan bahwa aktifitas politis sebuah perusahaan (corporate political activity) tergantung pada tingkat ketergantungan sumberdaya perusahaan terhadap partner politisnya. Berdasarkan resource dependence theory (teori ketergantungan sumberdaya - Pfeffer dan Salancik, 1978), penelitian ini juga akan menguji apakah perbedaan tingkat ketergantungan terhadap partner (baik bisnis maupun politis) akan menimbulkan konsekuensi yang berbeda terhadap kinerja perusahaan. Lebih lanjut, tingkat ketergantungan yang bagaimanakah yang akan memperkuat (atau memperlemah) modal sosial yang dimiliki oleh perusahaan?

\section{KAJIAN PUSTAKA DAN PENGEM- BANGAN HIPOTESA}

\section{Ikatan Bisnis}

Tindakan ekonomi berupa pertukaran barang atau jasa menitikberatkan pada hubungan antarindividu, dan network theory (teori jejaring Heide, 1994; Morgan and Hunt, 1994; Uzzi, 1997) berpendapat bahwa hubungan antar individu - social capital - sangat penting dalam mengkoordinasikan secara informal proses pertukaran tersebut. Melakukan aktifitas pengembangan jejaring dan interaksi personal dengan pelaku bisnis lainnya, eksekutif dan pemilik perusahaan membangun modal sosial tidak hanya dengan pelaku bisnis, namun juga dengan pejabat pemerintah. Penelitian ini mendefinisikan ikatan bisnis sebagai koneksi sosial yang dimiliki perusahaan dan berlangsung secara informal dengan organisasi bisnis, misalnya dengan pembeli, supplier, pesaing, dan pelaku bisnis lainnya (Sheng et al., 2011). Sedangkan ikatan politis adalah koneksi sosial yang dimiliki perusahaan dan berlangsung secara informal dengan pejabat pemerintah di beberapa tingkatan, baik di tingkat pusat dan daerah, maupun pejabat pada instansi yang mengatur usaha (misalnya pajak dan perizinan) (Li et al., 2009; Peng and Luo, 2000). 
Kedua ikatan tersebut tergantung pada interaksi personal dan jejaring sosial (hubungan informal) dibandingkan kontrak secara formal guna mendapatkan sumberdaya dan fasilitas lainnya. Namun keduanya secara fundamental berbeda terkait dengan sumberdaya dan waktu bekerjasamanya (Sheng et al., 2011). Ikatan bisnis menyediakan perusahaan sumberdayasumberdaya penting terkait dengan pasar. Pertama, ikatan bisnis menyediakan informasiinformasi penting yang tidak tersedia di pasar, misalnya produk baru yang akan diluncurkan pesaing (Heide and John, 1992), sehingga perusahaan lebih baik dalam menyiapkan tanggapannya. Perusahaan juga akan lebih mampu mengantisipasi peristiwa-peristiwa penting yang terjadi di pasar karena partner bisnisnya membagi informasi terkait hal tersebut (Lusch and Brown, 1996). Perusahaan juga dapat mendapatkan informasi terkait partner mana yang bisa dipercaya dan yang tidak dari jejaring bisnis yang mereka miliki (Poppo and Zenger, 2002). Kedua, interaksi sosial yang intens akan memfasilitasi pertukaran pengetahuan (Rindfleisch and Moorman, 2001; Saxenian, 1996), sehingga utilisasi dari pengetahuan yang dimiliki perusahaan akan meningkat (Cohen and Levinthal, 1990) dan tentunya kinerja perusahaan juga akan meningkat. Ketiga, jejaring bisnis yang luas akan menunjukkan reputasi perusahaan sehingga legitimasi sosial perusahaan akan meningkat (Dacin et al., 2007; Rao et al., 2008). Dari penjelasan tersebut dapat disimpulkan bahwa modal sosial yang dimiliki perusahaan melalui interaksi yang intens dan dekat dengan partner bisnisnya mampu meningkatkan kinerja bisnisnya. Sehingga,

$\mathrm{H}_{1}$ : Terdapat pengaruh positif ikatan bisnis yang dimiliki terhadap kinerja (a) keuangan dan (b) pemasaran perusahaan.

\section{Ikatan Politis}

Sedangkan ikatan politis membantu perusahaan mendapatkan sumberdaya-sumberdaya yang terkait dengan peraturan (Sheng et al., 2011). Pertama, arah kebijakan pemerintah dalam pembangunan akan sangat menentukan keberlangsungan hidup sebuah perusahaan di negara yang sedang berkembang, sehingga ikatan politis akan menjadikan perusahaan memiliki akses kepada pengambil kebijakan (Hillman et al., 1999) guna mendapatkan kebijaksanaan yang menguntungkan bagi perusahaan. Kedua, pemerintahan Indonesia mengontrol banyak sumberdaya strategis, baik yang terkait dengan government expenditures (misalnya: pembangunan infrastruktur), subsidi, pajak, maupun perizinan bagi industri tambang dan industri strategis lainnya (Fisman, 2001), sehingga kedekatan hubungan akan mempermudah penguasaan sumberdaya-sumberdaya strategis yang dapat menunjang kinerja perusahaan. Ketiga, ikatan politis dengan pemerintahan yang sedang menjabat juga memberikan legitimasi bahwa kegiatan usaha yang dilakukan oleh perusahaan sangat dibutuhkan dan dijalankan sesuai peraturan (Suchman, 1995), sehingga perusahaan akan menerima dukungan dari pemerintah lebih dari yang lain dengan perlakuan yang khusus pula (Sheng et al., 2011). Dalam kondisi demikian, perusahaan dengan jejaring politis yang kuat akan memiliki kinerja yang positif. Sehingga,

$\mathrm{H}_{2}$ : Terdapat pengaruh positif ikatan politis yang dimiliki terhadap kinerja (a) keuangan dan (b) pemasaran perusahaan.

\section{Perbandingan Pengaruh Ikatan Bisnis dan Politis}

Sheng et al. (2011) beragumentasi bahwa ikatan bisnis akan memiliki kontribusi terhadap kinerja lebih besar dibandingkan ikatan politis, dikarenakan ikatan bisnis memiliki orientasi jangka panjang dibandingkan ikatan politis. Dalam ikatan bisnis, mengingat dua perusahaan memiliki kepentingan yang sama, maka mereka akan bekerjasama untuk mengoptimalkan keuntungan bersama (Ghosh and John, 1999; Lusch and Brown, 1996). Semakin tinggi interaksi yang dilakukan, kepercayaan yang ada akan tumbuh dan berkembang (Morgan and Hunt, 1994), sehingga perilaku oportunis dari salah satu pihak dapat terminimalisir (Ganesan, 1994) karena orientasi hubungan jangka panjang. Sedangkan politisi, mereka cenderung berorientasi jangka pendek guna memfasilitasi jabatan politis yang hendak atau sedang diembannya (Ganesan, 1994). Ketika ikatan memiliki orientasi jangka waktu yang pendek, maka kemungkinan perusahaan untuk terlibat dalam perilaku oprtuis akan meningkat (Rokkan et al., 2003). Bahkan Shleifer and Vishny (1994) dan Dinc (2005) menemukan bahwa politisi cenderung menggunakan kedekatannya 
dengan pebisnis untuk mendapatkan keuntungan jangka pendeknya guna membiayai kebijakan populisnya, meskipun secara bisnis hal tersebut tidak menguntungkan. Sehingga,

$\mathrm{H}_{3}$ : Pengaruh positif ikatan bisnis akan lebih besar pengaruhnya terhadap kinerja (a) keuangan dan (b) pemasaran perusahaan dibandingkan ikatan politis.

\section{Ketergantungan pada Partner}

Pfeffer and Salancik (1978) mendefinisikan interdependensi (ketergantungan) antara dua organisasi akan terjadi bilamana tujuan salah satu pihak tidak akan tercapai tanpa adanya sumberdaya dari pihak yang lain. Studi terdahulu menghubungkan konsep interdependensi dengan konsep kekuasaan (mis: Casciaro dan Piskorski, 2005, Gulati and Sytch, 2007), yang dikembangkan berdasarkan konsep dari teori power-dependence relations (Emerson, 1962). Menurut teori ini, kekuasaan terdapat pada ketersediaan sumberdaya-sumberdaya alternatif (mis: Brass, 1984; Kumar et al., 1998). Dalam konteks penelitian ini, ketergantungan terhadap partner akan dibagi menjadi dua, yakni ketergantungan terhadap partner bisnis dan politis. Berikut ini adalah ilustrasi ketergantungan yang pertama: Perusahaan A akan mempunyai kekuasaan lebih besar dibandingkan partner bisnisnya (Perusahaan B) bilamana Perusahaan A dapat menjual produknya ke pembeli selain Perusahaan B dengan harga yang sepadan atau lebih baik, vice versa. Selanjutnya, teori ini juga mengatakan bahwa kekuasaan terdapat pada tingkat konsentrasi dari pertukaran yang terjadi (mis: Burt, 1982; Casciaro and Piskorski, 2005). Bilamana Perusahaan A menjual produknya lebih dari $75 \%$ kepada Perusahaan B, maka dapat dikatakan Perusahaan B mempunyai kekuasaan lebih besar dari Perusahaan A, vice versa. Contoh tersebut juga berlaku untuk ketergantungan terhadap partner politis, dimana Perusahaan A akan memiliki ketergantungan yang tinggi terhadap partner politisnya (Politisi B) bila mereka tidak menemukan patron lain yang dapat menyediakan sumberdaya politis atau sebagian besar sumberdaya politisnya disuplai oleh partner Politisi $\mathrm{B}$, vice versa.

Menurut Emerson (1962), terdapat dua jenis ketergantungan antar perusahaan, yakni ketergantungan yang asimetris dan keter- gantungan yang berimbang. Ketergantungan yang asimetris menunjukkan adanya perbedaan kekuasaan antara satu perusahaan dengan partnernya (Casciaro and Piskorski, 2005), yang mana perusahaan tersebut bisa jadi lebih atau kurang tergantung terhadap partnernya. Dalam konteks penelitian ini, contoh pertama di atas menjukkan bahwa Perusahaan A pada posisi yang kurang tergantung terhadap Perusahaan B, sedangkan contoh kedua menunjukkan yang sebaliknya. Sedangkan ketergantungan yang berimbang menunjukkan situasi dimana kedua belah pihak mempunyai tingkat ketergantungan yang sama besar (Gulati and Sytch, 2007). Penelitian ini lebih menitikberatkan pada ketergantungan yang asimetris, mengingat ketergantungan yang berimbang memerlukan kedua belah pihak untuk memberikan respon, yang mana dalam penelitian ini tidak dilakukan.

Peneliti berargumen bahwa tingkat ketergantungan terhadap partner (baik bisnis maupun politis) akan memoderasi pengaruh hubungan yang ada terhadap kinerja perusahaan. Bila ketergantungan perusahaan terhadap partner bisnisnya tinggi, maka kepercayaan dan komitmen akan berkembang (Morgan and Hunt, 1994; Poppo et al., 2008), mengingat ketergantungan yang tinggi akan meningkatkan interaksi yang ada diantara keduanya (Nahapiet and Ghoshal, 1998). Hal inilah yang menjadikan pengaruh ikatan bisnis terhadap kinerja perusahaan akan menguat bilamana ketergantungannya tinggi dibandingkan rendah. Hal yang sama juga berlaku bila perusahaan memiliki ketergantungan yang tinggi terhadap partner politisnya. Meskipun partner politis akan meminta banyak dukungan (secara ekonomi) ke perusahaan untuk menunjang promosi jabatan politisnya (Shleifer and Vishny, 1994), namun banyaknya sumberdaya strategis yang dapat dimanfaatkan melalui kebijakan yang dibuat oleh partner politis menjadikan kinerja perusahaan juga akan meningkat. Sehingga hipotesa berikut diajukan:

$\mathrm{H}_{4}$ : Pengaruh ikatan bisnis terhdap (a) kinerja keuangan dan (b) kinerja pemasaran perusahaan akan dimoderasi oleh ketergantungan terhadap partner bisnis yang dimiliki.

$\mathrm{H}_{5}$ : Pengaruh ikatan bisnis terhadap (a) kinerja keuangan dan (b) kinerja pemasaran perusahaan akan dimoderasi oleh ketergantungan terhadap partner politis yang dimiliki. 


\section{METODOLOGI PENELITIAN}

Konsisten dengan definisi dari Sheng et al. (2011), peneliti mengoperasionalkan ikatan bisnis sebagai kedekatan manajer atau permilik perusahaan mempunyai hubungan baik dengan partner usahanya dan mengukurnya dengan 6 pertanyaan yang dikembangkan oleh Dubini dan Aldrich (1991) dan Peng and Luo (2000) menggunakan 7 skala Likert. Definisi yang sama juga digunakan untuk mengoperasionalkan ikatan politis (Sheng et al., 2011) sebagai kedekatan manajer atau pemilik perusahaan dengan pejabat pemerintah atau pimpinan partai politik. Enam pertanyaan digunakan berdasarkan item yang dikembangkan oleh $\mathrm{Li}$ and Zhang (2007), Peng and Luo (2000), dan Xin and Pearce (1996) dan diukur dengan menggunakan skala yang sama, yakni 7 skala Likert. Interdependensi merupakan ketergantungan antara perusahaan dengan partner dalam bisnis maupun politis, dimana pengukurannya menggunakan item yang dikembangkan oleh Gulati and Sytch (2007) yang diukur dengan 6 skala Likert. Adapun kinerja perusahaan menggunakan item yang dikembangkan oleh $\mathrm{Li}$ and Zhang (2007) dan Zhou, Yim and Tse (2005) menggunakan 5 skala Likert.

Penggunaan skala yang berbeda (yaitu 5, 6, dan 7 skala Likert) dilakukan sebagai salah satu cara untuk mengurangi efek selfgenerated validity (Feldman and Lynch, 1988) berdasarkan saran dari Podsakoff et al. (2003). Penelitian ini juga melakukan balancing order, yakni mengurutkan pertanyaan tidak secara berurutan (misalnya, kinerja perusahaan diletakkan di awal, diikuti oleh ikatan bisnis dan politis, serta interdependensi). Penelitian ini juga menggunakan beberapa variabel kontrol, misalnya pendidikan, posisi, jenis industri, jumlah karyawan, omzet, perusahaan yang dimiliki, asosiasi yang diikuti, afiliasi dengan parpol, maupun pelanggan utama (apakah pemerintahan atau swasta). Selain itu, penelitian ini mengontrol dukungan pemerintah (Sheng et al., 2011) dan ketidakpastian permintaan dan teknologi (Jaworski and Kohli, 1993).

Penelitian ini menggunakan proportional random sampling, dengan menyebarkan 300 kuesioner kepada anggota Kamar Dagang Indonesia-KADIN Surabaya (beranggotakan sebanyak 7.011 perusahaan), Himpunan Pengusaha Muda Indonesia-HIPMI Surabaya (ber- anggotakan sebanyak 603 perusahaan), Gabungan Pengusaha Konstruksi-GAPENSI Surabaya (sebanyak 490 perusahaan) dan komunitas Tangan Di Atas-TDA (sebanyak 303 perusahaan). Menggunakan data dari KADIN yang membawahi semua asosiasi pengusaha sudah cukup, namun beberapa detail alamat kuta dapatkan dari asosiasi yang lebih spesifik seperti diatas.

Kuesioner yang dikembalikan sebanyak 154 (response rate sebesar 51,33\%) dengan waktu penelitian antara awal Februari hingga akhir April 2012. Responden laki-laki menjadi mayoritas (119 orang, 77,3\%). Terdapat 63 responden yang berusia diatas 35 tahun, sedangkan yang berusia dibawah 35 tahun sebanyak 91 orang $(59,1 \%)$. Lebih dari 94\% (145 orang) telah mendapatkan pendidikan hingga di perguruan tinggi, dimana posisi manajer dimiliki oleh 67 orang, sedangkan pemilik sebanyak 87 orang $(56,5 \%)$. Sebagian besar responden (63\%) menduduki jabatan yang dimiliki lebih dari 3 tahun. Industri jasa cukup dominan (67 perusahaan, 43,5\%), diikuti dengan kontraktor (25 perusahaan), manufaktur (16 perusahaan), dan lainnya. Terdapat 47 perusahaan yang memiliki karyawan di atas 50 orang, sedangkan sisanya memiliki karyawan kurang dari jumlah tersebut. Proporsi relatif beimbang antara perusahaan yang memiliki omzet diatas atau kurang dari Rp. 2,5 milyar. Terdapat 37 orang yang memiliki perusahaan lebih dari satu, dimana mereka secara sukarela menggabungkan diri kepada 1 asosiasi (105 orang) dan lebih dari 2 asosiasi (49 orang). Hanya 26 orang yang terafiliasi dengan partai politik, sedangkan sisanya tidak terafiliasi dengan partai politik. Yang cukup menarik adalah, sebagian besar pelanggan menyatakan bahwa pelanggan utama mereka adalah kalangan swasta, sedangkan instansi pemerintah hanya 33 perusahaan $(21,4 \%)$.

\section{HASIL PENELITIAN}

Tabel 1 menyajikan hasil uji validitas dan reliabilitas. Terlihat bahwa item yang digunakan hampir semuanya memiliki factor loading yang melebihi 0,500 (Hair et al., 2009), kecuali item terakhir dari ketergantungan terhadap partner politis dan dihapus untuk analisa selanjutnya. Adapun Cronbach's Alpha semuanya memiliki nilai lebih dari 0,700 . Hasil tersebut menyata- 
kan bahwa konstruk penelitian yang digunakan telah memenuhi kriteria valid dan reliabel. Tabel 2 menyajikan analisa deskriptif dan matriks korelasi, yang mana hubungan yang ada sesuai dengan prediksi sebelumnya.

Tabel 1: Hasil Uji Validitas dan Realibilitas

\begin{tabular}{|c|c|c|c|c|c|c|}
\hline Kode & Item & $\begin{array}{l}\text { Faktor } \\
\text { Loading }\end{array}$ & $\begin{array}{l}\text { Eigen- } \\
\text { value }\end{array}$ & $\underset{\%}{\text { Cumulative }}$ & $\begin{array}{l}\text { Item-to-total } \\
\text { Correlation }\end{array}$ & $\begin{array}{l}\text { Cronbach's } \\
\text { Alpha }\end{array}$ \\
\hline \multicolumn{7}{|c|}{ Kinerja Keuangan } \\
\hline KK1 & Laba/keuntungan dari investasi perusahaan & 0,855 & \multirow{3}{*}{2,003} & \multirow{3}{*}{66,767} & 0.639 & \multirow{3}{*}{0,750} \\
\hline KK2 & Pertumbuhan penjualan & 0,836 & & & 0.610 & \\
\hline KK3 & $\begin{array}{l}\text { Pengurangan biaya yang dikeluarkan dalam proses penjualan } \\
\text { produk }\end{array}$ & 0,757 & & & 0.502 & \\
\hline \multicolumn{7}{|c|}{ Kinerja Pemasaran } \\
\hline \multicolumn{7}{|c|}{ Dalam 2 (dua) tahun terakhir dibandingkan dengan perusahaan pesaing utama, perusahaan kami relatif mengalami peningkatan dalam hal: } \\
\hline KP1 & Loyalitas/kesetiaan pelanggan & 0,864 & \multirow{3}{*}{1,550} & \multirow{3}{*}{71,041} & 0.504 & \multirow{3}{*}{0,724} \\
\hline KP2 & Kepuasan pelanggan & 0,868 & & & 0.464 & \\
\hline KP3 & Nilai guna pelanggan (manfaat yang diterima dari pelanggan) & 0,691 & & & 0.353 & \\
\hline \multicolumn{7}{|c|}{ Ikatan Bisnis } \\
\hline BT1 & Yang menyuplai perusahaan kami (supplier) & 0,838 & \multirow{6}{*}{3,868} & \multirow{6}{*}{64,459} & 0.760 & \multirow{6}{*}{0,888} \\
\hline $\mathrm{BT} 2$ & Yang menjadi pelanggan perusahaan kami (customers) & 0,891 & & & 0.833 & \\
\hline BT3 & Yang menjadi pesaing perusahaan kami (competitors) & 0,814 & & & 0.726 & \\
\hline BT4 & Yang menjadi partner pemasaran kami (collaborators) & 0,862 & & & 0.786 & \\
\hline BT5 & $\begin{array}{l}\text { Yang menjadi partner pengembangan usaha kami } \\
\text { (collaborators) }\end{array}$ & 0,702 & & & 0.584 & \\
\hline BT6 & $\begin{array}{l}\text { Yang menjadi partner pengembangan teknologi kami } \\
\text { (collaborators) }\end{array}$ & 0,687 & & & 0.564 & \\
\hline \multicolumn{7}{|c|}{ Ikatan Politis } \\
\hline \multicolumn{7}{|c|}{ Manajer atau pemilik perusahaan kami ... } \\
\hline PT1 & $\begin{array}{l}\text { Mengembangkan hubungan yang baik dengan pejabat } \\
\text { pembuat peraturan dan organisasi pendukungnya (misalnya: } \\
\text { Bappeprov, Kantor Pajak, dan lainnya). }\end{array}$ & 0,825 & \multirow{6}{*}{3,614} & \multirow{6}{*}{77,971} & 0.575 & \multirow{6}{*}{0,865} \\
\hline PT2 & $\begin{array}{l}\text { Menjaga hubungan pribadi yang baik dengan pejabat di } \\
\text { berbagai instansi (misalnya: TNI/POLRI, pemkot/pemprov, } \\
\text { dan lainnya) }\end{array}$ & 0,840 & & & 0.695 & \\
\hline PT3 & $\begin{array}{l}\text { Menjaga hubungan pribadi yang baik dengan pejabat di ber- } \\
\text { bagai tingkatan (misalnya:kotamadya, provinsi, dan lainnya) }\end{array}$ & 0,836 & & & 0.639 & \\
\hline PT4 & $\begin{array}{l}\text { Hingga saat ini, hubungan perusahaan kami dengan kalangan } \\
\text { pemerintahan berjalan dengan baik. }\end{array}$ & 0,840 & & & 0.766 & \\
\hline PT5 & $\begin{array}{l}\text { Perusahaan kami telah mengeluarkan dana yang tidak sedikit } \\
\text { untuk membina hubungan baik di kalangan pemerintahan. }\end{array}$ & 0,861 & & & 0.608 & \\
\hline PT6 & $\begin{array}{l}\text { Hubungan yang baik dengan kalangan pemerintahan telah } \\
\text { kami jalin sejak lama. }\end{array}$ & 0,860 & & & 0.695 & \\
\hline \multicolumn{7}{|c|}{ Ketergantungan terhadap partner bisnis } \\
\hline Ind1 & $\begin{array}{l}\text { Akan sangat beresiko dan sulit bila perusahaan kami tidak lagi } \\
\text { menjalin hubungan dengan partner bisnis kami (baik supplier, } \\
\text { customers, maupun collaborators) }\end{array}$ & 0.750 & \multirow{5}{*}{2.473} & \multirow{5}{*}{59.453} & 0.547 & \multirow{5}{*}{0.740} \\
\hline Ind2 & $\begin{array}{l}\text { Sangat banyak perusahaan lain yang bisa dijadikan partner } \\
\text { dalam melakukan bisnis. }\end{array}$ & 0.749 & & & 0.543 & \\
\hline Ind3 & $\begin{array}{l}\text { Banyak alternatif perusahaan lain yang bersedia menjalin } \\
\text { hubungan bisnis dengan perusahaan kami. }\end{array}$ & 0.703 & & & 0.505 & \\
\hline Ind4 & $\begin{array}{l}\text { Biaya akan sangat besar bila perusahaan kami memutuskan } \\
\text { hubungan dengan partner bisnis yang telah ada. }\end{array}$ & 0.671 & & & 0.475 & \\
\hline Ind5 & $\begin{array}{l}\text { Dibandingkan perusahaan lain, partner kami mempunyai } \\
\text { banyak kelebihan (akses pasar, besaran modal, dll) }\end{array}$ & 0.636 & & & 0.453 & \\
\hline \multicolumn{7}{|c|}{ Ketergantungan terhadap partner politis } \\
\hline Ind6 & $\begin{array}{l}\text { Akan sangat beresiko dan sulit bila perusahaan kami tidak lagi } \\
\text { menjalin hubungan dengan pejabat atau instansi pemerintahan. }\end{array}$ & 0.821 & \multirow{5}{*}{2.538} & \multirow{5}{*}{63.458} & 0.646 & \\
\hline Ind7 & $\begin{array}{l}\text { Sangat banyak pejabat atau instansi pemerintahan lain yang } \\
\text { perusahaan kami dapat menjalin hubungan. }\end{array}$ & 0.834 & & & 0.661 & \\
\hline Ind8 & Banyak alternatif pejabat atau instansi pemerintahan lain yang & 0.867 & & & 0.716 & \\
\hline Ind9 & $\begin{array}{l}\text { bersedia menjalin hubungan dengan perusahaan kami. } \\
\text { Biaya akan sangat besar bila perusahaan kami memutuskan } \\
\text { hubungan dengan pejabat atau instansi pemerintahan yang } \\
\text { telah ada. }\end{array}$ & 0.646 & & & 0.457 & 0.802 \\
\hline Ind10 & $\begin{array}{l}\text { Dibandingkan pejabat atau instansi pemerintahan, partner } \\
\text { kami mempunyai banyak kelebihan (akses kebijakan, modal } \\
\text { politis, dll) }\end{array}$ & & & & & \\
\hline
\end{tabular}

Catatan: Huruf yang tercetak miring dihapus karena faktor loading dan corrected item-to-total correlation dibawah persyaratan. 
Tabel 2: Standard Deviasi, Mean, dan Matriks Korelasi

\begin{tabular}{|c|c|c|c|c|c|c|c|c|c|c|c|c|c|c|c|c|c|c|c|c|c|}
\hline $\begin{array}{l}\text { Variabel } \\
\text { Penelitian }\end{array}$ & Mean & S.D. & 1 & 2 & 3 & 4 & 5 & 6 & 7 & 8 & 9 & 10 & 11 & 12 & 13 & 14 & 15 & 16 & 17 & 18 & 19 \\
\hline Pendidikan & 0.94 & 0.24 & 1.00 & & & & & & & & & & & & & & & & & & \\
\hline Posisi & 0.56 & 0.50 & -0.05 & 1.00 & & & & & & & & & & & & & & & & & \\
\hline Konstruksi & 0.16 & 0.37 & 0.11 & $0.39^{* *}$ & 1.00 & & & & & & & & & & & & & & & & \\
\hline Manufaktur & 0.10 & 0.31 & -0.01 & $-0.17^{*}$ & -0.15 & 1.00 & & & & & & & & & & & & & & & \\
\hline Jasa & 0.44 & 0.50 & $0.16^{*}$ & 0.14 & $-0.39^{* *}$ & $-0.30^{* *}$ & 1.00 & & & & & & & & & & & & & & \\
\hline Jumlah karyawan & 0.69 & 0.46 & -0.11 & 0.02 & -0.13 & $-0.24^{* *}$ & 0.07 & 1.00 & & & & & & & & & & & & & \\
\hline Omzet & 0.49 & 0.50 & $-0.20^{*}$ & 0.03 & $-0.22^{* *}$ & $-0.21^{* *}$ & 0.13 & $0.63^{* *}$ & 1.00 & & & & & & & & & & & & \\
\hline $\begin{array}{l}\text { Perusah aan yang } \\
\text { dimiliki }\end{array}$ & 0.76 & 0.43 & $0.31^{* *}$ & $-0.25^{* *}$ & -0.12 & 0.09 & -0.03 & 0.09 & -0.02 & 1.00 & & & & & & & & & & & \\
\hline $\begin{array}{l}\text { As osiasi yang } \\
\text { diikuti }\end{array}$ & 0.69 & 0.48 & $0.30^{* *}$ & 0.00 & -0.01 & $-0.27^{* *}$ & $0.16^{*}$ & $0.40^{* *}$ & $0.29^{* *}$ & 0.11 & 1.00 & & & & & & & & & & \\
\hline $\begin{array}{l}\text { Afiliasi dengan } \\
\text { parpol }\end{array}$ & 0.83 & 0.38 & $0.41^{* *}$ & $-0.33^{* *}$ & 0.15 & 0.15 & $-0.20^{*}$ & -0.11 & $-0.18^{*}$ & 0.07 & 0.00 & 1.00 & & & & & & & & & \\
\hline Pelanggan utama & 1.79 & 0.41 & -0.06 & -0.01 & $0.19^{*}$ & 0.07 & $-0.40^{* *}$ & -0.14 & $-0.18^{*}$ & 0.15 & $-0.18^{*}$ & $0.23^{* *}$ & 1.00 & & & & & & & & \\
\hline $\begin{array}{l}\text { Ketiida kpastian } \\
\text { lingku ngan }\end{array}$ & 4.16 & 0.95 & -0.05 & $0.37^{* *}$ & $0.19^{*}$ & 0.14 & -0.03 & -0.08 & -0.07 & -0.15 & $-0.28^{* *}$ & -0.08 & $-0.19^{*}$ & 1.00 & & & & & & & \\
\hline $\begin{array}{l}\text { Dukungan } \\
\text { kebijakan }\end{array}$ & 4.05 & 1.12 & $0.25^{* *}$ & $-0.40^{* *}$ & -0.13 & -0.13 & 0.13 & 0.02 & 0.03 & $0.54^{* *}$ & 0.07 & 0.03 & 0.03 & $-0.50^{* *}$ & 1.00 & & & & & & \\
\hline Ikatan bisnis & 4.71 & 1.04 & -0.09 & 0.00 & -0.03 & -0.02 & 0.02 & -0.03 & 0.12 & -0.05 & -0.03 & $-0.16^{*}$ & -0.02 & -0.03 & 0.02 & 1.00 & & & & & \\
\hline Ikatan politis & 4.61 & 1.01 & -0.09 & -0.12 & -0.07 & -0.02 & -0.09 & 0.04 & 0.12 & 0.12 & 0.07 & -0.11 & -0.06 & -0.04 & 0.08 & $0.41^{* *}$ & 1.00 & & & & \\
\hline $\begin{array}{l}\text { Ketergan tungan } \\
\text { pada bi snis }\end{array}$ & 4.73 & 0.77 & 0.06 & -0.08 & 0.11 & -0.11 & -0.08 & 0.14 & 0.01 & 0.06 & $0.18^{*}$ & -0.06 & -0.02 & 0.03 & 0.06 & $0.27^{* * *}$ & $0.40^{*}$ & 1.00 & & & \\
\hline $\begin{array}{l}\text { Ketergan tugan } \\
\text { pada politis }\end{array}$ & 4.33 & 0.92 & 0.02 & $-0.20^{*}$ & $-0.20^{*}$ & -0.07 & 0.04 & 0.12 & 0.07 & 0.05 & 0.14 & -0.08 & -0.06 & -0.11 & 0.12 & $0.30^{* * *}$ & $0.38^{* *}$ & $0.61^{* *}$ & 1.00 & & \\
\hline Ki nerja pemasaran & 3.87 & 0.67 & -0.03 & 0.12 & 0.09 & 0.01 & -0.11 & 0.07 & 0.04 & -0.10 & $0.16^{*}$ & -0.06 & 0.12 & 0.05 & $-0.20^{*}$ & $0.24^{* * *}$ & $0.41^{* *}$ & $0.53^{* * *}$ & $0.41^{* * *}$ & 1.00 & \\
\hline Ki nerja keuangan & 3.88 & 0.69 & 0.12 & -0.02 & 0.00 & -0.02 & 0.01 & 0.00 & 0.01 & -0.06 & $0.19^{*}$ & 0.02 & 0.04 & 0.01 & -0.03 & $0.16^{*}$ & $0.24 *$ & $0.48^{* *}$ & $0.40^{* *}$ & $0.64^{* *}$ & 1.00 \\
\hline
\end{tabular}




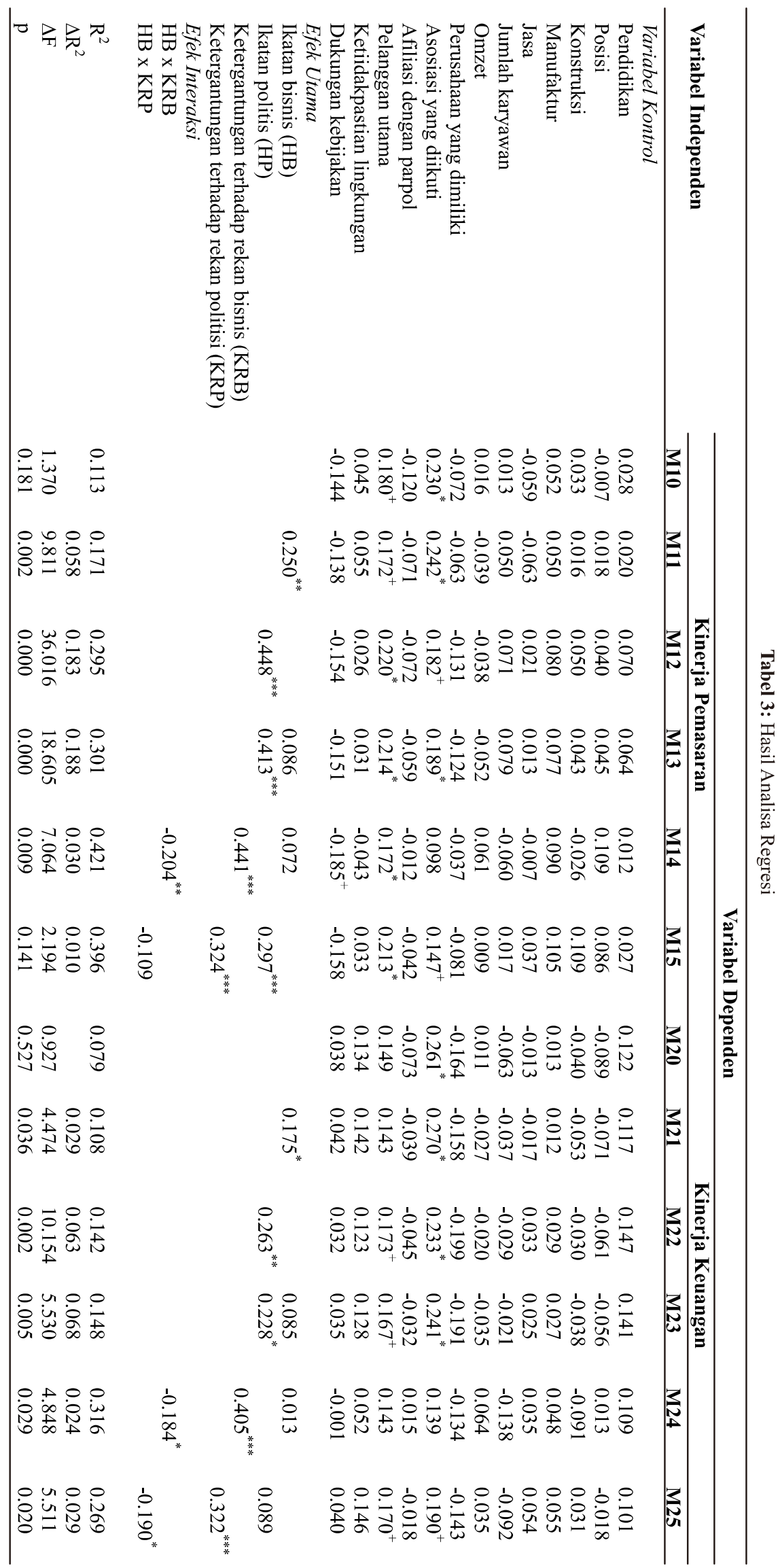


Hipotesa pertama menyatakan bahwa ikatan bisnis yang dimiliki perusahaan akan berkontribusi positif terhadap kinerja pemasaran dan keuangan perusahaan. Hasil analisa analisa menunjukkan bahwa ikatan bisnis memiliki kontribusi yang positif dan signifikan terhadap kinerja pemasaran $(\beta=0,250, p<0,01)$ dan kinerja keuangan perusahaan $(\beta=0,175$, $p<0,05)$; sehingga $\mathrm{H}_{1}$ dapat diterima.. Hipotesa kedua memprediksi bahwa ikatan politis yang dimiliki perusahaan juga akan berkontribusi positif terhadap kinerja perusahaan. Hasil analisa regresi menunjukkan bahwa ikatan politis memiliki kontribusi yang positif dan signifikan terhadap kinerja pemasaran $(\beta=0,448, p<0,001)$ dan kinerja keuangan perusahaan $(\beta=0,263, p<0,01)$; sehingga $\mathrm{H}_{2}$ dapat diterima. Hipotesa ketiga menyatakan bahwa ikatan bisnis dan politis secara simultan berkontribusi positif terhadap kinerja perusahaan. Hasil analisa regresi menunjukkan bahwa hanya ikatan politis yang memiliki kontribusi yang positif dan signifikan terhadap kinerja pemasaran $(\beta=0,413, \quad p<0,001)$ dan kinerja keuangan perusahaan $(\beta=0,405$, $p<0,001)$; sehingga $\mathrm{H}_{3}$ tidak dapat diterima.

Untuk menguji efek moderasi yang diajukan pada hipotesa kedua dan ketiga, peneliti menggunakan regresi berjenjang mengingat variabel bebas dan moderatornya merupakan variabel continuous. Menurut Aiken and West (1991) dan Cohen et al. (2003), penggunaan regresi berjenjang mampu mempertahankan sifat kontinyu dari sebuah variabel tanpa kehilangan informasi atau menurunkan kekuatan untuk mendeteksi efek moderasi. Mengingat variabel-variabel tersebut mempunyai multikolinearitas yang tinggi, maka peneliti menggunakan metode centering seperti yang disarankan oleh Frazier et al. (2004).

Hipotesa 4 memprediksi bahwa pengaruh positif ikatan bisnis terhadap kinerja perusahaan akan dimoderasi oleh ketergantungan pada partner bisnis. Hasil analisa menunjukkan bahwa terdapat pengaruh moderasi yang signifikan pada pengaruh ikatan bisnis pada kinerja pemasaran $(\beta=-0,204, p<0,05)$ maupun keuangan perusahaan $(\beta=-0,184, p<0,05)$, sehingga $\mathrm{H}_{4}$ dapat diterima. Hipotesa 5 memprediksi bahwa pengaruh positif ikatan politis terhadap kinerja perusahaan akan dimoderasi oleh ketergantungan pada partner politis. Hasil analisa menunjukkan bahwa tidak terdapat pengaruh moderasi yang signifikan pada pengaruh ikatan bisnis pada kinerja pemasaran ( $\beta=-$ $0,109, p=0,141)$, namun signifikan pada kinerja keuangan perusahaan $(\beta=-0,190, \quad p<0,05)$, sehingga $\mathrm{H}_{5}$ sebagian dapat diterima.

Menggunakan prosedur dari Aiken and West (1991) dan Cohen et al. (2003), peneliti menggambarkan efek moderasi tersebut (Gambar 1). Kinerja pemasaran akan mencapai titik tertinggi ( $\bar{X}=0,426)$ ketika perusahaan memiliki ikatan bisnis yang tinggi dan pada saat yang sama juga memiliki ketergantungan yang tinggi terhadap partnernya. Bilamana ketergantungannya rendah, kinerja pemasaran mencapai titik terendah $(\bar{X}=-0,576)$ meskipun perusahaan memiliki ikatan bisnis yang tinggi dengan partnernya.

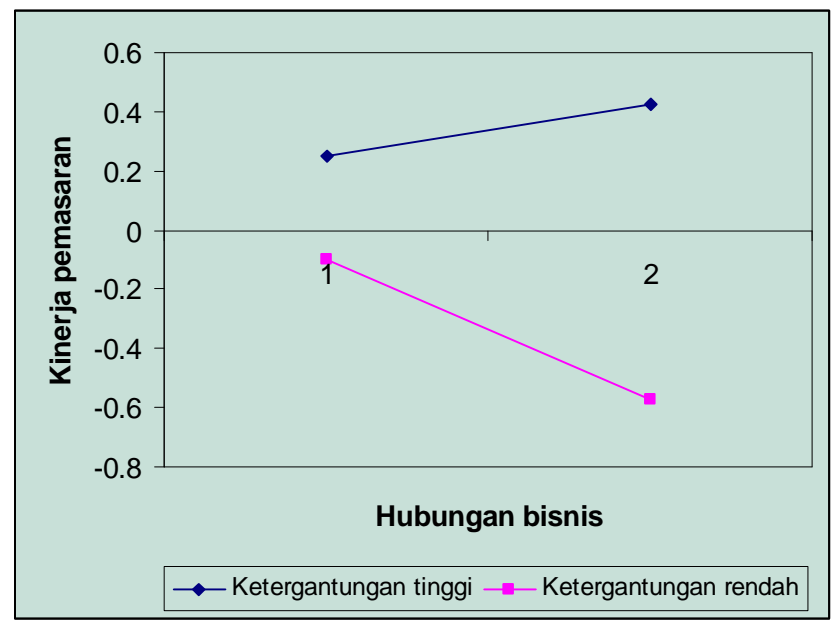

Gambar 1 - Efek Moderasi terhadap Kinerja Pemasaran 

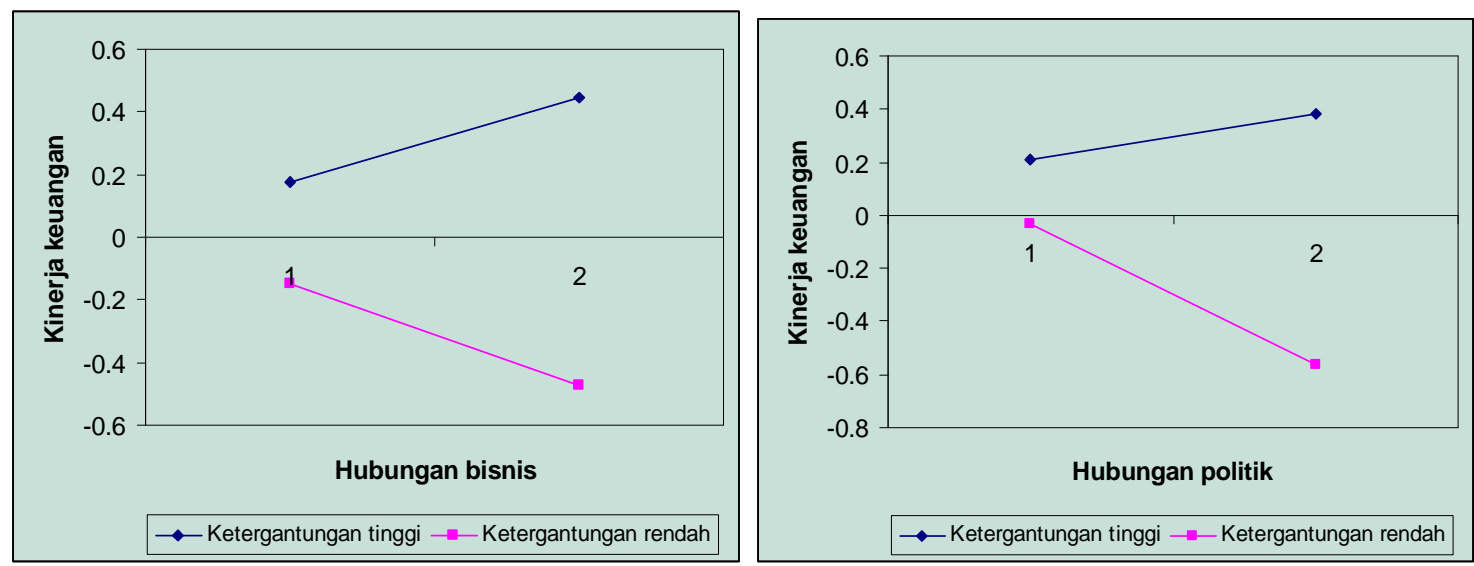

Gambar 2 - Efek Moderasi terhadap Kinerja Keuangan

Perbedaan antara ketergantungan yang tinggi ( $\bar{X}=0,250)$ dengan yang rendah $(\bar{X}=-0,100)$ tidak terlalu besar bilamana perusahaan memiliki ikatan bisnis yang rendah dengan partnernya.

Pola yang sama juga terlihat pada kinerja keuangan (Gambar 2), dimana perbedaan antara ketergantungan yang tinggi $(\bar{X}$ $=0,177)$ dengan yang rendah $(\bar{X}=-0,150)$ tidak terlalu besar bilamana perusahaan memiliki ikatan bisnis yang rendah dengan partnernya. Namun ketika ikatan bisnisnya tinggi, ketergantungan yang tinggi justru akan meningkatkan kinerja keuangan pada titik yang tertinggi ( $\bar{X}=0,444)$ dibandingkan ketika mereka memiliki ketergantungan yang rendah terhadap partner bisnisnya ( $\bar{X}=-0,471)$. Terkait dengan ikatan politis, kinerja keuangan akan mencapai titik tertinggi ( $\bar{X}=0,382)$ ketika perusahaan memiliki ikatan bisnis yang tinggi dan pada saat yang sama juga memiliki ketergantungan yang tinggi terhadap partnernya. Bilamana ketergantungannya rendah, kinerja keuangan mencapai titik terendah $(\bar{X}=-0,561)$ meskipun perusahaan memiliki ikatan bisnis yang tinggi dengan partnernya. Perbedaan antara ketergantungan yang tinggi ( $\bar{X}=0,209$ ) dengan yang rendah $(\bar{X}=-0,030)$ tidak terlalu besar bilamana perusahaan memiliki ikatan bisnis yang rendah dengan partnernya.

\section{KESIMPULAN}

Penelitian ini dilakukan guna menjawab pertanyaan ikatan apakah yang berkontribusi terbesar pada kinerja perusahaan, apakah ikatan bisnis atau ikatan politis? Hasil penelitian ini menunjukkan bahwa masing-masing ikatan tersebut berpengaruh secara positif terhadap kinerja perusahaan, namun bila dilakukan uji secara simultan terlihat bahwa ikatan politis lebih dominan dalam berkontribusi terhadap kinerja perusahaan. Hal ini tentunya bertentangan dengan hasil penelitian Sheng dkk. (2011) dan $\mathrm{Wu}$ (2011) bahwa ikatan bisnis lebih berpengaruh dibandingkan ikatan politis pada kinerja perusahaan. Sampel dalam penelitian ini, yakni anggota KADIN dan organisasi lainnya, memiliki keyakinan bahwa pemerintah memegang sumberdaya strategis yang penting bagi kelangsungan hidup perusahaannya. Meskipun pemerintah menjadi pelanggan minoritas bagi bisnis mereka, namun ketika penelitian ini menjadikannya sebagai variabel kontrol terlihat bahwa pengaruhnya cukup signifikan. Fakta tersebut menjadikan hasil penelitian ini bertolak belakang dengan hasil penelitian sebelumnya (Sheng dkk., 2011; Wu, 2011) yang menggunakan kalangan bisnis dengan pelanggan murni non-pemerintah.

Pertanyaan kedua yang hendak dijawab melalui penelitian ini adalah dalam kondisi bagaimanakah ikatan bisnis maupun politis pada kinerja perusahaan akan menguat atau melemah? Berdasarkan resource dependence theory (Pfeffer dan Salancik, 1978), peneliti menggunakan ketergantungan terhadap partner (baik partner bisnis maupun politis) sebagai variabel moderator. Kesimpulan yang didapat adalah ketergantungan terhadap partner (baik partner bisnis maupun politis) memperkuat pengaruh ikatan yang dimiliki terhadap kinerja perusahaan bilamana ikatannya sangat kuat. Meskipun ikatan dengan partnernya kuat namun pada saat yang sama ketergantungannya rendah, maka kinerja perusahaan mencapai titik 
terendah. Hal ini dikarenakan tingkat ketergantungan merefleksikan interaksi dan volume transaksi (baik bisnis dan politis) yang dilakukan perusahaan dengan partnernya, semakin rendah ketergantungannya maka potensi keuntungan yang akan didapatkan dari ikatan yang dimiliki tidak akan dapat dioptimalkan. Dengan kata lain, perusahaan tidak dapat memaksimalkan modal social yang dimilikinya (Nahapiet dan Ghoshal) bilamana ketergantungannya rendah (Casciaro dan Piskorski, 2005; Gulati dan Sytch, 2007).

Hasil penelitian ini mempunyai implikasi manajerial sebagai berikut: Pertama, sesuai dengan yang dikemukakan oleh Hillman dan Hitt (1999) dan Hillman dkk. (1999), memiliki koneksi politis dengan penguasa merupakan strategi yang patut dipertimbangkan bagi perusahaan dalam rangka meningkatkan dan menjaga kinerja perusahaannya. Hal tersebut akan semakin penting bilamana pelanggan utamanya adalah pemerintah. Kedua, meskipun dalam penelitian ini ikatan bisnis kalah kontribusinya terhadap kinerja perusahaan, namun penelitian sebelumnya menyatakan bahwa berhubungan baik dengan sesama pebisnis, terutama dengan partner bisnis, juga perlu dilakukan karena banyak potensi yang akan didapatkan (Sheng et al., 2011; Wu, 2011). Ketiga, memiliki ketergantungan yang tinggi (namun berimbang) (Pfeffer dan Salancik, 1978) akan memberikan manfaat lebih dibandingkan tingkat ketergantungan yang rendah terhadap partner (baik bisnis maupun politis). Dengan melakukan interaksi yang lebih sering dengan volume transaksi yang tinggi, menjadikan perusahaan memiliki kemungkinan lebih tinggi untuk mengoptimalkan peluang yang ada melalui ikatan yang dimilikinya.

Selain implikasi manajerial, penelitian ini juga mempunyai implikasi akademis. Pertama, penelitian ini memperluas konteks penelitian serupa yang selama ini didominasi oleh China (Sheng et al., 2011; Wu, 2011) ke konteks Indonesia. Sebagai sesama Negara yang sedang tumbuh dan berkembang, dinamisme lingkungan bisnis relatif serupa sehingga tantangan yang dimiliki perusahaan juga relatif sama. Memiliki modal sosial, baik dengan partner bisnis maupun partner politis, sangat krusial sebagai penopang kemajuan perusahaan. Kedua, penelitian ini juga menemukan bahwa sampel penelitian juga berpengaruh ter- hadap hasil penelitian. Bilamana Sheng et al. (2011) dan $\mathrm{Wu}$ (2011) menggunakan perusahaan yang fokus melayani kalangan bisnis menjadikan ikatan bisnis lebih dominan kontribusinya terhadap kinerja perusahanan, maka penelitian ini yang memfokuskan pada anggota KADIN yang mana instansi pemerintah menjadi pelanggan utamanya menjadikan ikatan politis lebih berperan dalam kinerja perusahaan. Ketiga, penelitian ini juga memasukkan perspektif ketergantungan (resource dependence theory - Pfeffer dan Slaancik, 1978) yang awalnya digunakan dalam tulisan konseptual yang dimiliki oleh Hillman dan Hitt (1999). Pengujian secara empiris ini menguatkan pendapat mereka bahwa tingkat ketergantungan juga berperan terhadap aktifitas perusahaan untuk berpolitik (corporate political activity Hillman dan Hitt, 1999; Hillman dkk., 1999).

Meskipun penelitian ini telah dilakukan dengan baik, namun masih terdapat beberapa keterbatasan. Pertama, penelitian ini terbatas pada perusahaan yang terdaftar pada KADIN, GAPENSI, HIPMI, TDA wilayah Surabaya. Tentunya dengan memperluas konteks, baik asosiasi ataupun daerah lainnya, akan meningkatkan generalizability dari hasil yang ditemukan dalam penelitian ini. Selain itu, melakukan penelitian yang cross-culture akan menjanjikan hasil yang lebih bermanfaat bagi perusahaan yang akan melakukan ekspansi di luar Indonesia. Kedua, penelitian ini menggunakan crosssectional yang mungkin kurang menggambarkan dampak sesungguhnya dari modal social. Menjalin ikatan tidaklah dapat dilakukan dalam waktu yang singkat, sehingga pengaruhnya pun tidak dapat dirasakan dalam waktu yang bersamaan. Penelitian selanjutnya dapat menggunakan penelitian longitudinal untuk menangkap fenomena ini. Ketiga, item yang digunakan untuk merepresentasikan modal social mungkin tidak mencakup modal social yang dimiliki oleh sebuah perusahaan. Tentunya penelitian selanjutnya dapat lebih merinci masing-masing partner dengan tingkat ikatan yang berbedabeda sehingga hasil analisa yang didapatkan akan lebih akurat.

\section{DAFTAR PUSTAKA}

Ambler, T., and M. Witzel. 2004. Doing Business in China. London: Routledge Curzon. 
Brass, DJ. 1984. Being in the Right Place: A Structural Analysis of Individual Influence in an Organization. Administrative Science Quarterly. 29 (4). 518-539.

Burt, RS. 1982. Toward a Structural Theory of Action: Network Models of Social Structure, Perception, and Action. New York: Academic Press.

Casciaro, T., and MJ. Piskorski. 2005. Power Imbalance, Mutual Dependence, and Constraint Absorption: A Closer Look at Resource Dependence Theory. Administrative Science Quarterly. 50 (2). 167-199.

Cohen, WM. and DA. Levinthal. 1990. Absorptive Capacity: A New Perspective on Learning and Innovation. Administrative Science Quarterly. 35 (1). 128 52.

Dacin, MT., C. Oliver, and J-P. Roy. 2007. The Legitimacy of Strategic Alliances: An Institutional Perspective. Strategic Management Journal. 28 (2). 169-87.

Dieleman, M., and WM. Sachs. 2008. Coevolution of Institutions and Corporations in Emerging Economies: How the Salim Group Morphed into an Institution of Suharto's Crony Regime. Journal of Management Studies. 45 (7). 1274-1300.

Dinc, IS. 2005. Politicians and Banks: Political Influences on Government-Owned Banks in Emerging Markets. Journal of Financial Economics. 77 (2). 453-79.

Du, J-L., Y. Lu, and Z-G. Tao .2008. Economic Institutions and FDI Location Choice: Evidence from U.S. Multinationals in China. Journal of Comparative Economics. 36 (3). 412-29.

Dubini, P., and H. Aldrich .1991. Personal and Extended Networks Are Central to the Entrepreneurial Process. Journal of Business Venturing. 6 (5). 305-313.

Emerson, R. 1962. Power-dependence Relations. American Sociological Review. 27 (1). 31-41
Faccio, M. 2006. Politically Connected Firms. American Economic Review. 96 (1). 369-86.

Feldman, J. M., dan Lynch Jr., JG. 1988. Self Generated Validity and Other Effects of Measurement on Belief, Attitude, Intention and Behavior. Journal of Applied Psychology. 73 (3). 421-35.

Fisman, R. 2001 Estimating the Value of Political Connections. American Economic Review. 91 (4).1095-1102.

Ganesan, S. 1994. Determinants of Long-Term Orientation in Buyer-Seller Relationships. Journal of Marketing. 58 (April). $1-19$.

Ghosh, M. and G. John. 1999. Governance Value Analysis and Marketing Strategy. Journal of Marketing. 63 (Special Issue). 131-45.

Gu, FF., K. Hung, and DK. Tse. 2008. When Does Guanxi Matter? Issues of Capitalization and Its Dark Sides. Journal of Marketing. 72 (July). 12-28.

Gulati R., dan M. Sytch. 2007. Dependence Asymmetry and Joint Dependence in Interorgania tional Relationships: Effects of Embeddedness on a Manufacturer's Performance in Procurement Relationships. Administrative Science Quarterly. 52 (1). 32-69.

Heide, JB. 1994. Interorganizational Governance in Marketing Channels. Journal of Marketing. 58 (January). 71-85.

Heide, JB. and KH. Wathne .2006. Friends, Businesspeople, and Relationship Roles: A Conceptual Framework and a Research Agenda. Journal of Marketing. 70 (July). 90-103.

Heide, JB. and G. John. 1992. Do Norms Matter in Marketing Relationships? Journal of Marketing. 56 (April). 3244.

Hillman, A., and Hitt, M. 1999 Corporate Political Strategy Formulation: A Model of Approach, Participation and Strategy Decisions. Academy of Management Review. 20 (1). 193-214. 
Hillman, AJ., A. Zardkoohi, and L. Bierman .1999. Corporate Political Strategies and Firm Performance: Indications of Firm-Specific Benefits from Personal Service in the U.S. Government. Strategic Management Journal. 20 (1). 67-81.

Jaworski, BJ. and AK. Kohli. 1993. Market Orientation: Antecedents and Conse quences. Journal of Marketing. 57 (July). 53-70.

Khwaja, AI., and A. Mian. 2005. Do Lenders Favor Politically Connected Firms? Rent Provision in an Emerging Financial Market. Quarterly Journal of Economics. 120 (4). 1371-1411.

Kumar, N., LK. Scheer, dan J-B. EM. Steenkamp. 1998. Interdependence, Punitive Capability, and the Reciprocation of Punitive Actions in Channel Relationships. Journal of Marketing Research. 35 (2). 225-235.

Li, H-Y., and Y. Zhang. 2007. The Role of Managers' Political Networking and Functional Experience in New Venture Performance: Evidence from China's Transition Economy. Strategic Management Journal. 28 (8). 791-804.

Li, JJ., L. Poppo, and KZ. Zhou. 2008. Do Managerial Ties in China Always Produce Value? Competition, Uncertainty, and Domestic vs. Foreign Firms. Strategic Management Journal. 29 (4). 383-400.

Li, JJ., KZ. Zhou, and AT. Shao. 2009. Competitive Position, Managerial Ties, and Profitability of Foreign Firms in China: An Interactive Perspective. Journal of International Business Studies. 40 (2). 339-52.

Lusch, RF. and JR. Brown. 1996. Interdependency, Contracting, and Relational Behavior in Marketing Channels. Journal of Marketing. 60 (4). 19-38.

Morgan, RM. and SD. Hunt. 1994. The Commitment-Trust Theory of Relationship Marketing. Journal of Marketing. 58 (4). 20-38.
Nahapiet, J. and S. Ghoshal. 1998. Social Capital, Intellectual Capital, and the Organizational Advantage. Academy of Management Review. 23 (2). 242-266.

Peng, MW. 2003. Institutional Transitions and Strategic Choices. Academy of Management Review. 28 (2). 275-296.

Peng, MW., and Luo, Y. 2000. Managerial Ties and Firm Performance in a Transition Economy: The Nature of a MicroMacro Link. Academy of Management Journal. 43 (3). 486-501.

Pfeffer, J., dan GR. Salancik. 1978. The External Control of Organizations: A Resource Dependence Perspective. Harper \& Row: New York.

Podsakoff, PM., SB. MacKenzie, J. Lee, dan N.P. Podsakoff. 2003. Common Method Biases in Behavioral Research: A Critical Review of the Literature and Recommended Remedies. Journal of Applied Psychology. 88 (5). 879-903.

Poppo, L., and TR. Zenger. 2002. Do Formal Contracts and Relational Governance Function as Substitutes or Complements? Strategic Management Journal. 23 (8). 707-725.

Poppo, L., KZ. Zhou, and S-M. Ryu. 2008. Alternative Origins to Interorganizational Trust: An Interdependence Perspective on the Shadow of the Past and the Shadow of the Future. Organization Science. 19 (1). 39-55.

Rao, RS., RK. Chandy, and JC. Prabhu. 2008. The Fruits of Legitimacy: Why Some New Ventures Gain More from Innovation than Others. Journal of Marketing. 72 (July). 58-75.

Rindfleisch, A., and C. Moorman. 2001. The Acquisition and Utilization of Information in New Product Alliances: A Strength of Ties Perspective. Journal of Marketing. 65 (2). 1-18.

Rokkan, AI., JB. Heide and KH. Wathne. 2003. Specific Investments in Marketing Relationships: Expropriation and Bonding Effects. Journal of Marketing Research. 40 (May). 210-24. 
Saxenian, AL. 1996. Inside-Out: Regional Networks and Industrial Adaptation in Silicon Valley and Route 128. Citiscape: A Journal of Policy Development and Research. 2 (2). 41-60.

Sheng, S-B., KZ. Zhou and JJ. Li. 2011. The Effects of Business and Political Ties on Firm Performance: Evidence from China. Journal of Marketing. 75 (1). 115 .

Shleifer, A., and RW. Vishny. 1994. Politicians and Firms. Quarterly Journal of Economics. 109 (4). 995-1025.

Siegel, J. 2007. Contingent Political Capital and International Alliances: Evidence from South Korea. Administrative Science Quarterly, 52 (4). 621-66.

Suchman, MC. 1995. Managing Legitimacy: Strategic and Institutional Approaches. Academy of Management Review. 20 (3). 571-610.

Uzzi, B. 1997. Social Structure and Competition in Interfirm Networks:
The Paradox of Embeddedness. Administrative Science Quarterly. 42 (1). 35-67.

Wu, J. 2011. Asymmetric Roles of Business Ties and Political Ties in Product Innovation. Journal of Business Research. 64 (5). 1151-1156.

Xin, KR. and JL. Pearce. 1996 Guanxi: Connections as Substitutes for Formal Institutional Support. Academy of Management Journal. 39 (6). 1641-58.

Zhou, KZ., and L. Poppo. 2010. Exchange Hazards, Relational Reliability, and Contracts in China: The Contingent Role of Legal Enforceability. Journal of International Business Studies. 41 (5). 861-81.

Zhou, KZ., CK. Yim and DK. Tse. 2005. The Effects of Strategic Orientations on Technology and Market-Based Breakthrough Innovations. Journal of Marketing. 69 (April). 42-60. 